\title{
ESTIMATING THE RESIDUAL OPERATING LIFE OF WOODEN STRUCTURES IN HIGH HUMIDITY CONDITIONS
}

\author{
Aleksandr Chernykh¹, Dmitry Korolkov², Denis Nizhegorodtsev³, Tatiana Kazakevich4, Shirali Mamedov ${ }^{5}$ \\ 1,2,3,4,5 Saint Petersburg State University of Architecture and Civil Engineering \\ Vtoraja Krasnoarmeyskaya st., 4, Saint Petersburg, Russia
}

${ }^{1}$ Corresponding author: ag1825831@mail.ru

\begin{abstract}
Introduction: The paper addresses the issue of using regression equations to determine the residual operating life of structures made of wood of various species in high humidity conditions. Purpose of the study: The study is aimed at deriving general equations for calculation of the ultimate life of wooden structures using univariate regression equations for subsequent calculation of the residual operating life (option 1), or equations for immediate calculation of the residual operating life (option 2). Methods: Univariate regression equations are used: linear, logarithmic, seconddegree polynomial, power, exponential, natural exponential, and hyperbolic. Results: The authors derive general equations for calculation of the ultimate life of wooden structures for subsequent calculation of the residual operating life (option 1), and equations for immediate calculation of the residual operating life (option 2), presenting advantages and disadvantages of both options. They propose an algorithm to process the obtained results in case the calculation is carried out using several equations at once. The authors also present an example of calculating the residual operating life using the second option. Discussion: Based on the proposed relationships, it is possible to determine the residual operating life of any wooden structures under any operating conditions.
\end{abstract}

\section{Keywords}

Residual operating life, regression equations, wooden structures, humidity.

\section{Introduction}

Wood is one of the oldest materials used in construction. Besides, it is an essential finishing material we cannot do without when building structures, especially residential ones. Wood is still widely used in both exterior and interior finishing. In recent years, the construction of eco-friendly wooden houses has got a second wind.

Wood is both a traditional and modern material. For a while, it gave way to concrete, brick, and other materials. However, engineered wood resumed its rightful place and now it plays an important role in the construction of residential buildings, including high-rise ones (up to 18 stories), public buildings, bridges, sport and industrial facilities. Wood resources recover naturally and relatively quickly. Therefore, the use of wood in construction addresses the issue of sustainable development in society. The share of wooden structures in construction increases rapidly in almost the entire world, and even in those regions that have not significant wood resources. Timber merchants pay much attention to the development of woodworking technologies, improvement of woodworking equipment. New methods of sawing wood of various species, drying and zero-waste processing, joining and gluing pieces make it possible to obtain durable structures of high quality.
Wood has many valuable properties. It is used to manufacture most of the important items, workpieces, and structures for welfare improvement. Wood has a relatively low density $\left(500 \ldots 600 \mathrm{~kg} / \mathrm{m}^{3}\right)$, high strength to weight ratio, low thermal conductivity, and sound insulation characteristics. Among its main advantages, low electrical conductivity and high corrosion resistance can be mentioned. Due to its low electrical conductivity, it can be used as an electrical insulating material for wiring. Such important quality of wood as its eco-friendliness shall be noted as well. Wood is a product of wildlife and it does not emit any harmful substances. Due to its use in construction, it is possible to reduce greenhouse gas emissions into the atmosphere. Obviously, we shall take into account the effect of impregnation compounds intended to increase the protective properties of construction wood. And when such compounds are applied with no procedural violations, the quality of wood will only improve.

Among the disadvantages of wood as a building material, the following can be mentioned: anisotropy of wood; the presence of defects in the material (knots, cracks); the presence of residual deformations in wooden structures; changes in the volume and shape under the action of humidity. Most of the issues related to wooden structures can be compensated for with: a proper design 
and suitable wood products; a combination of wood with other fire-resistant, sound-proof or heat-insulating materials; treatment of wooden structures with protective chemical compounds.

All properties of wood mentioned above highlight its significance in our life. Wood remains an essential material used for construction, exterior and interior finishing, creation of various exterior and interior elements, providing comfortable conditions and ensuring design safety of buildings and structures. That is why it is required to estimate the residual operating life of wooden structures.

Residual operating life is the total operating time of an item from the moment of monitoring its technical condition to the moment of reaching the limit state (Rules and Regulations NP-024-2000, State Standard GOST 27.002-2015). It is needed to determine how much longer wooden structures can be in use and what actions can be taken in case the calculated residual operating life is quite short.

\section{Methods}

To find a relationship between two variables, regression analysis is used.

The following regression equations are used most often.

1) Multiple linear regression:

$$
y=\alpha_{0}+\alpha_{1} \cdot x_{1}+\cdots+\alpha_{n} \cdot x_{n}+\varepsilon
$$

Linear regression with one regressor is its special case:

2) Polynomial regression:

$$
y=\alpha_{0}+\alpha_{1} \cdot x+\varepsilon
$$

$$
y=\alpha_{0}+\alpha_{1} \cdot x+\alpha_{2} \cdot x^{2}+\cdots+\alpha_{n} \cdot x^{n}+\varepsilon
$$

3) Power regression:

$$
y=\alpha_{0} \cdot x_{1}^{\alpha_{1}} \cdot \ldots \cdot x_{n}^{\alpha_{n}}+\varepsilon
$$

4) Exponential regression:

$$
y=\alpha_{0} \cdot \alpha_{1}^{x_{1}} \cdot \ldots \cdot \alpha_{n}^{x_{n}}+\varepsilon
$$

5) Natural exponential regression:

$$
y=e^{\left(\alpha_{0}+\alpha_{1} \cdot x_{1}+\cdots+\alpha_{n} \cdot x_{n}\right)}+\varepsilon
$$

6) Logarithmic regression:

7) Hyperbolic regression:

$$
y=\alpha_{0}+\alpha_{1} \cdot \ln x_{1}+\cdots+\alpha_{n} \cdot \ln x_{n}+\varepsilon
$$

$$
y=\alpha_{0}+\frac{\alpha_{1}}{x_{1}}+\cdots+\frac{\alpha_{n}}{x_{n}}+\varepsilon
$$

where

$\alpha_{0}, \alpha_{1}, \ldots, \alpha_{n}$ - regression equation parameters;

$\mathrm{x}_{0}, \mathrm{x}_{1}, \ldots, \mathrm{x}_{\mathrm{n}}$ - independent variables;

$\varepsilon$ - the error of approximation;

$\mathrm{y}$ - a dependent variable that can be found using the regression equation.

The equations listed above are multivariate. In real practice, univariate regression equations are used to simplify a problem being solved.

Erofeev et al. (2014) studied the strength of wood of various species in high humidity conditions over time using univariate regression equations. Operating time in high humidity conditions was chosen as an independent variable. The error of approximation was neglected since the true value of wood strength is not known (only the average value based on the test results is available).

Following the experimental research, regression equations were obtained for the compressive strength along/ across fibers and bending strength of wood depending on the duration of exposure to high humidity. Here, we present only those equations that have a determination coefficient of more than 0.85 or regression equations with the highest determination coefficient. 
Architecture and Engineering Volume 5 Issue 1

Table 1. Regression equations for the compressive strength of wood along fibers depending on the duration of exposure to high humidity

\begin{tabular}{|c|c|c|c|}
\hline No. & $\begin{array}{l}\text { Wood } \\
\text { species }\end{array}$ & Regression equation & $\begin{array}{l}\text { Determination } \\
\text { coefficient } R^{2}\end{array}$ \\
\hline \multirow{5}{*}{1} & \multirow{5}{*}{ Birch } & $y=86.465-2.319 x$ & 0.9893 \\
\hline & & $y=84.624-4.9792 \ln (x)$ & 0.9890 \\
\hline & & $y=87.802-3.6565 x+0.2675 x^{2}$ & 0.9999 \\
\hline & & $y=84.659 x^{-0.0614}$ & 0.9864 \\
\hline & & $y=86.621 e^{-0.0287 x}$ & 0.9916 \\
\hline \multirow{5}{*}{2} & \multirow{5}{*}{ Redwood } & $y=77.365-1.639 x$ & 0.9681 \\
\hline & & $y=75.911-3.3266 \ln (x)$ & 0.8648 \\
\hline & & $y=75.703+0.0235 x-0.3325 x^{2}$ & 0.9999 \\
\hline & & $y=75.94 x^{-0.0455}$ & 0.8586 \\
\hline & & $y=77.47 e^{-0.0225 x}$ & 0.9647 \\
\hline 3 & Pine & $y=52.288+14.619 x-2.6925 x^{2}$ & 0.9122 \\
\hline 4 & Spruce & $y=52.927+18.195 x-3.5075 x^{2}$ & 0.9373 \\
\hline 5 & Ash & $y=97.563+2.8785 x-1.3675 x^{2}$ & 0.7883 \\
\hline 6 & Oak & $y=66.348+6.6605 x-1.5175 x^{2}$ & 0.9880 \\
\hline 7 & Elm & $y=63.16+2.121 x-0.635 x^{2}$ & 0.8555 \\
\hline \multirow{2}{*}{8} & \multirow{2}{*}{ Maple } & $y=100.3-3.859 x$ & 0.8205 \\
\hline & & $y=90.213+6.2285 x-2.0175 x^{2}$ & 0.9999 \\
\hline \multirow{3}{*}{9} & \multirow{3}{*}{ Linden } & $y=80.9-3.287 x$ & 0.9378 \\
\hline & & $y=76.312+1.3005 x-0.9175 x^{2}$ & 0.9962 \\
\hline & & $y=81.382 e^{-0.0458 x}$ & 0.9282 \\
\hline
\end{tabular}

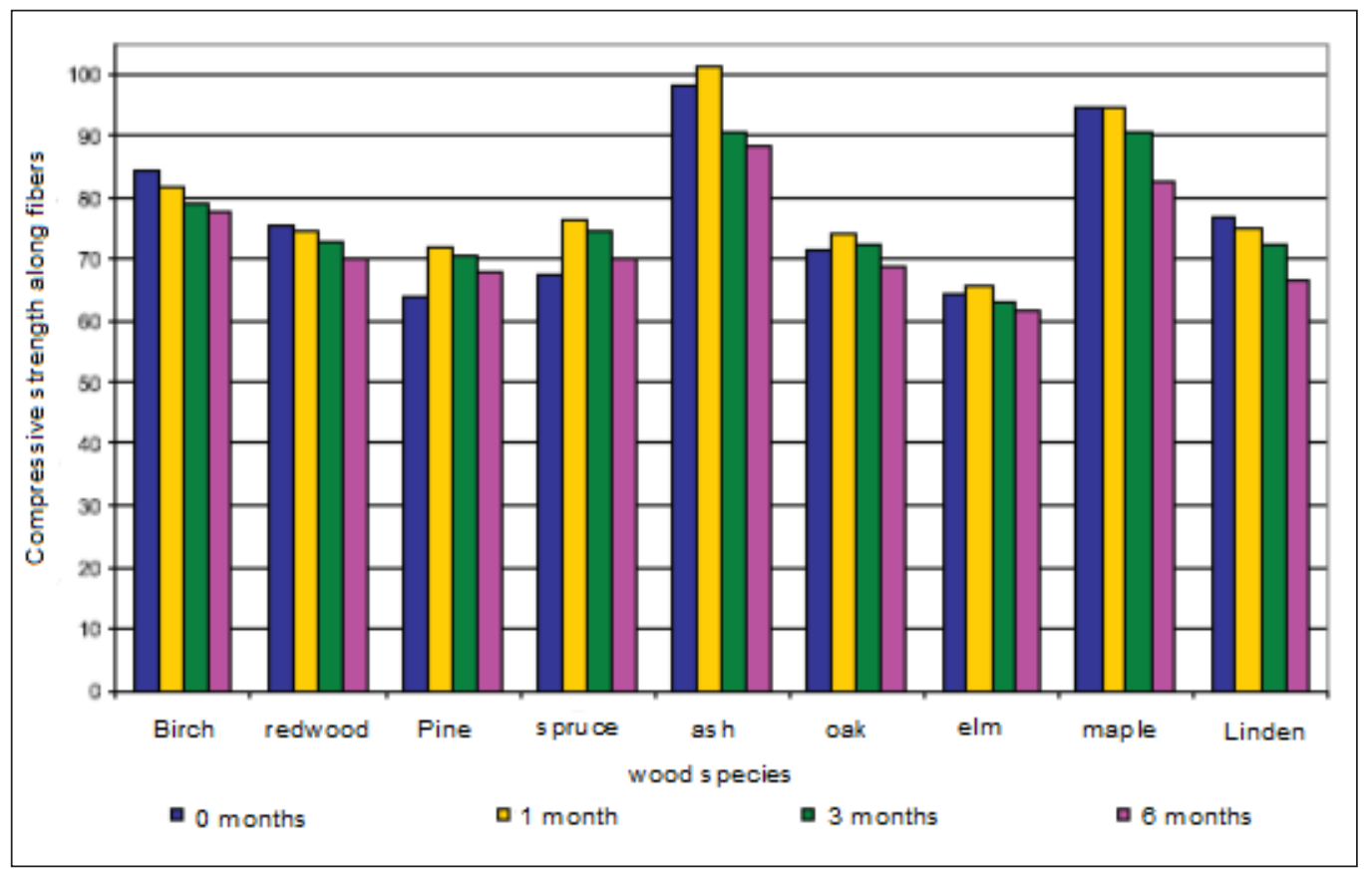

Figure 1. Changes in the strength of different wood species exposed to high humidity, compression along fibers 
Table 2. Regression equations for the compressive strength of wood across fibers depending on the duration of exposure to high humidity

\begin{tabular}{|c|c|c|c|}
\hline No. & $\begin{array}{l}\text { Wood } \\
\text { species }\end{array}$ & Regression equation & $\begin{array}{l}\text { Determination } \\
\text { coefficient } R^{2}\end{array}$ \\
\hline \multirow{5}{*}{1} & \multirow{5}{*}{ Birch } & $y=19.55-0.78 x$ & 0.9990 \\
\hline & & $y=18.90-1.63 \ln (x)$ & 0.9500 \\
\hline & & $y=19.425-0.655 x-0.025 x^{2}$ & 0.9998 \\
\hline & & $y=18.921 x^{-0.0927}$ & 0.9408 \\
\hline & & $y=19.643 e^{-0.0444 x}$ & 0.9974 \\
\hline \multirow{3}{*}{2} & \multirow{3}{*}{ Redwood } & $y=19.565-0.562 x$ & 0.8796 \\
\hline & & $y=18.565+0.438 x-0.2 x^{2}$ & 0.9687 \\
\hline & & $y=19.62 e^{-0.0312 x}$ & 0.8788 \\
\hline 3 & Pine & $y=9.0325+2.2665 x-0.4475 x^{2}$ & 0.7963 \\
\hline 4 & Spruce & $y=9.375+2.45 x-0.5 x^{2}$ & 0.9000 \\
\hline 5 & Ash & $y=25.063+0.0505 x-0.2575 x^{2}$ & 0.7580 \\
\hline 6 & Oak & $y=16.275+1.274 x-0.27 x^{2}$ & 0.9501 \\
\hline 7 & Elm & $y=17.663+1.1455 x-0.2925 x^{2}$ & 0.9943 \\
\hline \multirow{3}{*}{8} & \multirow{3}{*}{ Maple } & $y=25.165-1.004 x$ & 0.8608 \\
\hline & & $y=22.94+1.221 x-0.445 x^{2}$ & 0.9961 \\
\hline & & $y=25.324 e^{-0.0451 x}$ & 0.8507 \\
\hline \multirow{3}{*}{9} & \multirow{3}{*}{ Linden } & $y=19.33-1.065 x$ & 0.9140 \\
\hline & & $y=17.668+0.5975 x-0.3325 x^{2}$ & 0.9853 \\
\hline & & $y=19.564 e^{-0.0653 x}$ & 0.8984 \\
\hline
\end{tabular}

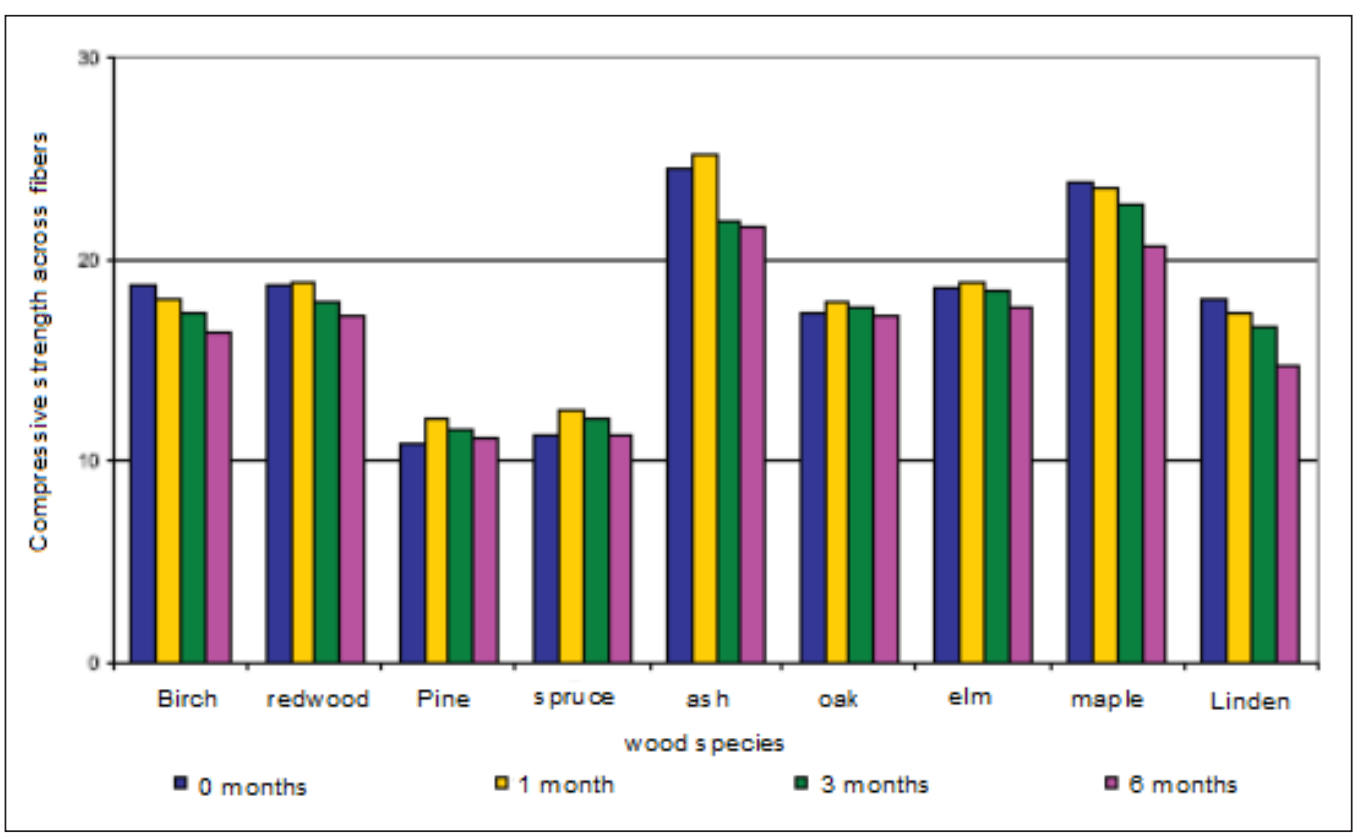

Figure 2. Changes in the strength of different wood species exposed to high humidity, compression across fibers 


\section{Architecture and Engineering Volume 5 Issue 1}

Table 3. Regression equations for the bending strength of wood depending on the duration of exposure to high humidity

\begin{tabular}{|c|c|c|c|}
\hline No. & $\begin{array}{l}\text { Wood } \\
\text { species }\end{array}$ & Regression equation & $\begin{array}{l}\text { Determination } \\
\text { coefficient } R^{2}\end{array}$ \\
\hline \multirow{5}{*}{1} & \multirow{5}{*}{ Birch } & $y=754.46-37.626 x$ & 0.9424 \\
\hline & & $y=726.46-83.154 \ln (x)$ & 0.9981 \\
\hline & & $y=805.18-88.351 x+10.145 x^{2}$ & 0.9972 \\
\hline & & $y=727.24 x^{-0.124}$ & 0.9996 \\
\hline & & $y=758.77 e^{-0.0564 x}$ & 0.9531 \\
\hline \multirow{5}{*}{2} & \multirow{5}{*}{ Redwood } & $y=577.65-22.032 x$ & 0.9987 \\
\hline & & $y=559.65-46.668 \ln (x)$ & 0.9716 \\
\hline & & $y=581.85-26.232 x+0.84 x^{2}$ & 0.9998 \\
\hline & & $y=560.22 x^{0.089}$ & 0.9654 \\
\hline & & $y=580.01 e^{-0.0422 x}$ & 0.9996 \\
\hline \multirow{5}{*}{3} & \multirow{5}{*}{ Pine } & $y=593.45-26.61 x$ & 0.9595 \\
\hline & & $y=570.77-55.191 \ln (x)$ & 0.8950 \\
\hline & & $y=577.58-10.735 x-3.175 x^{2}$ & 0.9704 \\
\hline & & $y=571.79 x^{0.105}$ & 0.8792 \\
\hline & & $y=597.4 e^{-0.00509 x}$ & 0.9528 \\
\hline 4 & Spruce & $y=319.68+42.984 x-10.44 x^{2}$ & 0.9664 \\
\hline \multirow{5}{*}{5} & \multirow{5}{*}{ Ash } & $y=831.78-26.856 x$ & 0.9748 \\
\hline & & $y=808.27-54.918 \ln (x)$ & 0.8839 \\
\hline & & $y=808.83-3.906 x-4.59 x^{2}$ & 0.9976 \\
\hline & & $y=809.02 x^{-0.072}$ & 0.8736 \\
\hline & & $y=834.58 e^{-0.0353 x}$ & 0.9696 \\
\hline 6 & Oak & $y=614.81+15.007 x-3.7125 x^{2}$ & 0.7225 \\
\hline 7 & Elm & $y=559.57+62.595 x-15.525 x^{2}$ & 1.000 \\
\hline \multirow{3}{*}{8} & \multirow{3}{*}{ Maple } & $y=875.93-60.885 x$ & 0.8988 \\
\hline & & $y=761.74+53.302 x-22.838 x^{2}$ & 1.000 \\
\hline & & $y=894.39 e^{-0.0868 x}$ & 0.8824 \\
\hline \multirow{2}{*}{9} & \multirow{2}{*}{ Linden } & $y=608.63-39.915 x$ & 0.8417 \\
\hline & & $y=515.81+52.897 x-18.563 x^{2}$ & 0.9873 \\
\hline
\end{tabular}

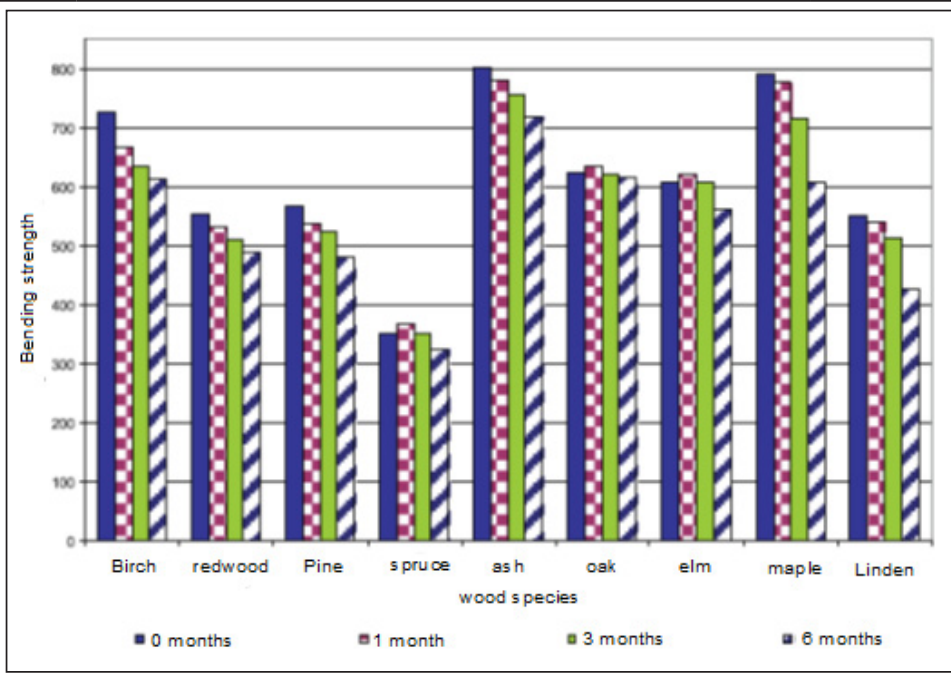

Figure 3. Changes in the bending strength of different wood species exposed to high humidity 
As compared with other approaches to the estimation of wooden structures' durability (Chaouch, 2011; Faydi et al., 2017; Hannouz, 2014; Khrulyov, 1981; Köhler, 2006; Lamov, 1999; Perret, 2017), this method is quite interesting as it used regression analysis, which can be applied to any structures and operating conditions.

\section{Results and Discussion}

According to the research results, it is possible to estimate the long-term strength of wood using univariate regression equations (with operating time as a variable). Then, the same equations can be used to estimate the residual operating life of wooden structures. It is assumed that operating conditions remain the same during the entire useful life of structures.

This idea can be implemented in two ways. The first one is as follows: if we know the minimum (design) strength of a wooden structure and a regression equation with established parameters, it is possible to determine the ultimate life of such a structure. Subtracting the time, during which it was actually in use, we obtain the residual operating life.

The ultimate life will be as follows.

In case of linear regression:

$$
R_{\text {min }}=a_{1} \cdot t+a_{0} \rightarrow t=\frac{R_{\min }-a_{0}}{a_{1}}
$$

In case of logarithmic regression:

$$
\begin{aligned}
& R_{\text {min }}= a_{1} \cdot \ln t+a_{0} \rightarrow \ln t=\frac{R_{\min }-a_{0}}{a_{1}} \rightarrow t= \\
&=\exp \left[\frac{R_{\min }-a_{0}}{a_{1}}\right]
\end{aligned}
$$

In case of polynomial regression: since second-order equations (parabolic regression) are presented, then the solution will be in the form of a solution to a quadratic equation.

$$
\begin{aligned}
R_{\text {min }}= & a_{2} \cdot t^{2}+a_{1} \cdot t+a_{0} \rightarrow a_{2} \cdot t^{2}+a_{1} \cdot t+ \\
& +a_{1} \cdot t+\left(a_{0}-R_{\text {min }}\right)=0 \\
& t=\frac{-a_{1} \pm \sqrt{a_{1}{ }^{2}-4 \cdot a_{2} \cdot\left(a_{0}-R_{\min }\right)}}{2 \cdot a_{2}}
\end{aligned}
$$

The solution has the following constraint: time cannot be a negative value.

In case of power regression:

$$
R_{\min }=a_{0} \cdot t^{a_{1}} \rightarrow t^{a_{1}}=\frac{R_{\min }}{a_{0}} \rightarrow t=\sqrt[a_{1}]{\frac{R_{\min }}{a_{0}}}
$$

The constraint will be as follows: $\alpha_{1}>1$.

If $\alpha_{1}$ is negative, then we shall divide 1 by $t$ obtained using equation (13).

The solution has the following constraint: time cannot be a negative value.

In case of natural exponential regression: let us present two possible options.

$$
\begin{aligned}
& R_{\text {min }}=a_{0} \cdot e^{a_{1} \cdot t} \rightarrow e^{a_{1} \cdot t}= \\
& =\frac{R_{\text {min }}}{a_{0}} \rightarrow a_{1} \cdot t=\ln \frac{R_{\text {min }}}{a_{0}} \rightarrow t=\frac{1}{a_{1}} \cdot \ln \frac{R_{\text {min }}}{a_{0}} \\
& R_{\text {min }}=e^{\left(a_{1} \cdot t+a_{0}\right)} \rightarrow a_{1} \cdot t+a_{0}= \\
& =\ln R_{\text {min }} \rightarrow t=\frac{1}{a_{1}} \cdot\left(\ln R_{\text {min }}-a_{0}\right)
\end{aligned}
$$

In case of exponential regression:

$R_{\text {min }}=\alpha_{0} \cdot \alpha_{1}^{t} \rightarrow \alpha_{1}^{t}=\frac{R_{\min }}{a_{0}} \rightarrow t=\log _{a_{1}} \frac{R_{\min }}{a_{0}}$

The constraints will be as follows: $\alpha_{1}>0$ и $\alpha_{1} \neq 1$. In case of hyperbolic regression:

$$
\begin{aligned}
& R_{\text {min }}=\alpha_{0}+\frac{\alpha_{1}}{t} \rightarrow \frac{\alpha_{1}}{t}= \\
& =R_{\text {min }}-\alpha_{0} \rightarrow t=\frac{\alpha_{1}}{R_{\text {min }}-\alpha_{0}}
\end{aligned}
$$

where

$\alpha_{0}$ - the initial value of the parameter (strength), MPa;

$\alpha_{1}$ - the rate of the parameter (strength) change, MPa/s;

$\alpha_{2}$ - the rate of the parameter (strength) change acceleration, $\mathrm{MPa} / \mathrm{s}^{2}$;

$R_{\min }$ - the minimum strength.

Since it is possible to apply several regression equations at once to some wood species, then, in that case, we shall take the arithmetic mean for the operating life. We also can accept the arithmetic mean when establishing the final value if the divergence from the mean does not exceed $10 \%$.

$$
t_{\text {mean }}=\frac{1}{n} \cdot \sum_{i=1}^{n} t_{i}
$$

In case of combined stress-strain state, it is required to estimate the ultimate life by several states at once. The least of the obtained values shall be taken as the final value. The least value shall be also chosen if the values are in the range from 10 to $20 \%$.

$$
T_{u l t}=\min \left\{\begin{array}{c}
T_{\text {ult } 1} \\
\ldots \\
T_{\text {ulti }}
\end{array}\right.
$$

The residual operating life of wooden structures will be as follows:

$$
T_{\text {res }}=t-t_{\text {serv }}
$$

where $t_{\text {serv }}$ is the actual service life of a structure.

It shall be noted that the equations derived to estimate the ultimate life of wooden structures can be applied to any operating conditions since these equations use abstract parameters $a$ and $b$.

These equations can be also applied in case of the simultaneous action of several variables.

Then, the residual operating life will be calculated as follows: 


$$
T_{\text {res }}=A \cdot\left[-\frac{1}{B} \cdot t_{\text {serv }}+T_{u l t}\right]
$$

The physical meaning of coefficient $A$ is that it reduces the initial (set) residual operating life of building structures due to the immaturity of the manufacturing technology as well as installation and assembly procedures, design errors, etc.

The physical meaning of coefficient $B$ is that it reduces the residual operating life of building structures during their use.

Therefore, coefficients $A$ and $B$ can be considered as safety factors (reduction coefficients).

In the general case, they will take values from 0 to 1 .

The disadvantage of this approach is that we need to know the type of regression equation in advance. Such equations are available not for every operating parameter and every wood species.

The second option is as follows: if we know the margin of the load-bearing capacity in wooden structures, it is possible to estimate their residual operating life.

It can be determined in the following way.

In case of linear regression:

$$
\Delta R=a_{1} \cdot \Delta t+a_{0} \rightarrow \Delta t=\frac{\Delta R-a_{0}}{a_{1}}
$$

\section{In case of logarithmic regression:}

$$
\begin{aligned}
& \Delta R=a_{1} \cdot \ln \Delta t+a_{0} \rightarrow \ln \Delta t= \\
& =\frac{\Delta R-a_{0}}{a_{1}} \rightarrow \Delta t=\exp \left[\frac{\Delta R-a_{0}}{a_{1}}\right]
\end{aligned}
$$

In case of polynomial regression: since second-order equations (parabolic regression) are presented, then the solution will be in the form of a solution to a quadratic equation.

$$
\begin{aligned}
& \Delta R=a_{2} \cdot(\Delta t)^{2}+a_{1} \cdot \Delta t+a_{0} \rightarrow a_{2} \cdot(\Delta t)^{2}+ \\
& +a_{1} \cdot \Delta t+\left(a_{0}-\Delta R\right)=0 \\
& \Delta t=\frac{-a_{1} \pm \sqrt{a_{1}{ }^{2}-4 \cdot a_{2} \cdot\left(a_{0}-\Delta R\right)}}{2 \cdot a_{2}}
\end{aligned}
$$

The solution has the following constraint: time cannot be a negative value.

In case of power regression:

$$
\Delta R=a_{0} \cdot(\Delta t)^{a_{1}} \rightarrow(\Delta t)^{a_{1}}=\frac{R_{\min }}{a_{0}} \rightarrow \Delta t=\sqrt[a_{1}]{\frac{\Delta R}{a_{0}}}
$$

The constraint will be as follows: $\alpha_{1}>1$.

If $a_{1}$ is negative, then we shall divide 1 by $t$ obtained using equation (26).

The solution has the following constraint: time cannot be a negative value.

In case of natural exponential regresion: let us present two possible options.

$$
\begin{aligned}
& \Delta R=a_{0} \cdot e^{a_{1} \cdot \Delta t} \rightarrow e^{a_{1} \cdot \Delta t}=\frac{\Delta R}{a_{0}} \rightarrow a_{1} \cdot \Delta t= \\
& =\ln \frac{\Delta R}{a_{0}} \rightarrow \Delta t=\frac{1}{a_{1}} \cdot \ln \frac{\Delta R}{a_{0}}
\end{aligned}
$$

$$
\begin{aligned}
& \Delta R=e^{\left(a_{1} \cdot \Delta t+a_{0}\right)} \rightarrow a_{1} \cdot \Delta t+a_{0}= \\
& =\ln \Delta R \rightarrow \Delta t=\frac{1}{a_{1}} \cdot\left(\ln \Delta R-a_{0}\right)
\end{aligned}
$$

In case of exponential regression:

$\Delta R=\alpha_{0} \cdot \alpha_{1}^{\Delta t} \rightarrow \alpha_{1}^{\Delta t}=\frac{\Delta R}{a_{0}} \rightarrow \Delta t=\log _{a_{1}} \frac{\Delta R}{a_{0}}$

The constraints will be as follows: $\alpha_{1}>0$ и $\alpha_{1} \neq 1$. In case of hyperbolic regression:

$$
\Delta R=\alpha_{0}+\frac{\alpha_{1}}{\Delta t} \rightarrow \frac{\alpha_{1}}{\Delta t}=\Delta R-\alpha_{0} \rightarrow \Delta t=\frac{\alpha_{1}}{\Delta R-\alpha_{0}}
$$

$\Delta R$ - the margin of the load-bearing capacity;

$\Delta t$ - the residual operating life.

Since it is possible to apply several regression equations at once to some wood species, then, in that case, we shall take the arithmetic mean for the final value of the residual operating life. We also can accept the arithmetic mean when establishing the final value if the divergence from the mean does not exceed $10 \%$.

$$
\Delta t_{\text {mean }}=\frac{1}{n} \cdot \sum_{i=1}^{n} \Delta t_{i}
$$

In case of combined stress-strain state, it is required to estimate the residual operating life by several states at once. The least of the obtained values shall be taken as the final value. The least value shall be also chosen if the values are in the range from 10 to $20 \%$.

$$
T_{\text {res }}=\min \left\{\begin{array}{c}
T_{\text {res } 1} \\
\cdots \\
T_{\text {res } i}
\end{array}\right.
$$

It is important to note that the residual operating life can be calculated only after it is established that the loadbearing capacity is ensured.

Another disadvantage of this approach is that we need to know the type of regression equation in advance.

Let us present an example of calculation using the second option.

\section{Confirmatory analysis and calculation of the residual operating life for a wooden beam}

Table 4. Summary of loads on a wooden beam (distance $-1.5 \mathrm{~m}$ )

\begin{tabular}{|c|c|c|c|c|}
\hline No. & Load & $\begin{array}{c}\text { Standard } \\
\text { load, } \mathrm{kg} / \mathrm{m}^{2}\end{array}$ & $\begin{array}{c}\text { Coefficient } \\
\mathrm{Y}^{\dagger}\end{array}$ & $\begin{array}{c}\text { Design load, } \\
\mathrm{kg} / \mathrm{m}^{2}\end{array}$ \\
\hline 1 & Slab weight & 149 & 1.1 & 183 \\
\hline 2 & Live load, $70 \mathrm{~kg} / \mathrm{m}^{2}$ & 105 & 1.2 & 126 \\
\hline & Total $(q)$ & 254 & & 309 \\
\hline
\end{tabular}

Operating conditions: heated space, high humidity. Wood species: birch, grade 1 .

\section{Normal stress analysis} $\mathrm{cm}$. 


$$
M=\frac{q \cdot l^{2}}{8}=\frac{309 \cdot 4^{2}}{8}=618 \mathrm{~kg} \cdot \mathrm{m}=61800 \mathrm{~kg} \cdot \mathrm{cm}
$$

According to Clause 7.9 of Regulations SP 64.13330.2017, the following condition shall be fulfilled:

$$
M / W_{\text {des }} \leq R_{b}^{\mathrm{des}}
$$

where $R_{b}^{\mathrm{des}}$ is the design bending strength of wood.

$$
R_{b}^{\text {des }}=R_{b}^{\mathrm{A}} \cdot m_{\mathrm{rup}} \cdot m_{\mathrm{t}} \cdot m_{\mathrm{m}} \cdot m_{\mathrm{temp}} \cdot m_{\mathrm{ull}}
$$

where $R_{b}^{\mathrm{A}}=24 \mathrm{MPa}$ is the design bending strength for loading mode $A$ (where $A$ is the loading mode No.); $m_{\text {rup }}=0.53$ is the rupture strength coefficient corresponding to loading mode $B ; m_{n}=1.1$ is the transition coefficient for birch wood; $m_{\mathrm{m}}=0.9$ is the coefficient taking into account operating conditions 3.1 (moisture conditions); $m_{\text {temp }}$ $=1.0$ is the coefficient taking into account temperature conditions; $m_{u l .}=1.0$ is the coefficient taking into account the estimated useful life of a structure.

$$
\begin{aligned}
& R_{b}^{\text {des }}=24 \cdot 0.53 \cdot 1.1 \cdot 0.9 \cdot 1 \cdot 1 \cdot 10= \\
& =125.9 \mathrm{~kg} / \mathrm{cm}^{2} \\
& W_{\text {des }}=\frac{b \cdot h^{2}}{6}=\frac{14 \cdot 20^{2}}{6}=933.33 \mathrm{~cm}^{3} \\
& M / W_{\text {des }}=61800 / 933.33=66.21 \frac{\mathrm{kg}}{\mathrm{cm}^{2}}<R_{b}^{\text {des }}= \\
& =125.9 \mathrm{~kg} / \mathrm{cm}^{2}
\end{aligned}
$$

The element meets the requirements of Regulations SP 64.13330.2017 regarding the strength under normal stresses.

\section{Shear stress analysis}

The element is subject to a transverse force:

$$
Q=\frac{q \cdot l}{2}=\frac{309 \cdot 4}{2}=618 \mathrm{~kg}
$$

The following condition shall be fulfilled:

$$
\frac{Q \cdot S_{\text {gross }}}{I_{\text {gross }} \cdot b_{\text {des }}} \leq R_{\text {sh }}^{\text {des }}
$$

where $S_{\text {gross }}$ and $I_{\text {gross }}$ is the static gross moment of inertia and gross moment of inertia of cross section, $R_{s h}^{\text {des }}$ is the design shear resistance of wood along fibers;

$$
\begin{aligned}
& R_{s h}^{\text {des }}=R_{s h}^{\mathrm{A}} \cdot m_{\text {rup }} \cdot m_{\mathrm{t}} \cdot m_{\mathrm{m}} \cdot m_{\text {temp }} \cdot m_{\text {u.l. }} \\
& R_{s h}^{\mathrm{A}}=2.7 \mathrm{MPa} ; m_{\text {rup }}=0.53 ; m_{\mathrm{t}}=1.3 \\
& m_{\mathrm{m}}=0.9 ; m_{\text {temp }}=1.0 ; m_{\text {u.l. }}=1.0 . \\
& R_{\text {sh }}^{\text {des }}=2.7 \cdot 0.53 \cdot 1.3 \cdot 0.9 \cdot 1 \cdot 1 \cdot 10= \\
& =16.74 \mathrm{~kg} / \mathrm{cm}^{2}
\end{aligned}
$$

$$
\begin{aligned}
& S_{\text {gross }}=\frac{b \cdot h^{2}}{8}=\frac{14 \cdot 20^{2}}{8}=700 \mathrm{~cm}^{3} \\
& I_{\text {gross }}=\frac{b \cdot h^{3}}{12}=\frac{14 \cdot 20^{3}}{12}=9333.33 \mathrm{~cm}^{4} \\
& \frac{Q \cdot S_{\text {gross }}}{I_{\text {gross }} \cdot b_{\text {des }}}=\frac{618 \cdot 700}{9333.33 \cdot 14}=3.31 \frac{\mathrm{kg}}{\mathrm{cm}^{2}}<R_{\text {sh }}^{\text {des }}=16.74 \mathrm{~kg} / \mathrm{cm}^{2}
\end{aligned}
$$

The element meets the requirements of Regulations SP 64.13330.2017 regarding the strength under shear stresses.

Let us determine the residual operating life.

The margin of the load-bearing capacity will be as follows.

For normal stresses:

$$
\begin{gathered}
R_{\text {act }}=\frac{66.21}{0.53 \cdot 1.1 \cdot 0.9 \cdot 1 \cdot 1 \cdot 10}=12.62 \mathrm{MPa} \\
\Delta R=24-12.62=11.38 \mathrm{MPa}
\end{gathered}
$$

For shear stresses:

$$
\begin{gathered}
R_{a c t}=\frac{3.31}{0.53 \cdot 1.3 \cdot 0.9 \cdot 1 \cdot 1 \cdot 10}=0.53 \mathrm{MPa} \\
\Delta R=2.7-0.53=2.17 \mathrm{MPa}
\end{gathered}
$$

Let us assume that the regression equation is known. It will have the following form:

$$
\Delta R=754.46-37.626 \cdot \Delta t
$$

Then, the residual operating life will be as follows:

$$
\Delta t=\frac{11.38-754.46}{-37.626}=19.7 \approx 20 \text { years }
$$

\section{Conclusions}

The authors analyzed regression equations for the compressive strength along/across fibers and bending strength of wood of various species over time. For each of them, they derived equations for the estimation of the ultimate life of wooden structures.

They presented two options for the calculation of the residual operating life using regression equations and identified disadvantages of both options.

The authors proposed the following: to take the arithmetic mean for the final value of the ultimate life if the ultimate life is determined using several regression equations at once, or if the divergence from the mean does not exceed $10 \%$. In case of combined stress-strain state or in case the divergence from the mean is in the range from 10 to $20 \%$, the least of the obtained values shall be taken as the final value.

Subtracting the time, during which the structures were actually in use, from the obtained value, we obtain the residual operating life of such structures (first option). In case of the second option, we can obtain the residual operating life right away.

The authors also presented the example of calculating the residual operating life of a wooden beam. 


\section{References}

Chaouch, M. (2011). Effet de l'intensité du traitement sur la composition élémentaire et la durabilité du bois traité thermiquement: développement d'un marqueur de prédiction de la résistance aux champignons basidiomycètes. DSc Thesis in Engineering. Nancy: Université Henri Poincaré - Nancy 1.

Erofeev, V. T., Startsev, O. V., Antoshkin, V. D., Gudozhnikov, S. S., Samolkina, E. G., Boldina, I. V and Makhonkov, A. Y. (2014). Estimation of strength of hardwood in high humidity conditions. Fundamental Research, No. 9 (Part 12), pp. 2630-2638.

Faydi, Y., Brancheriau, L., Pot, G. and Collet, R. (2017). Prediction of oak wood mechanical properties based on the statistical exploitation of vibrational response. BioResources, 12 (3), pp. 5913-5927. DOI : 10.15376/biores.12.3.5913-5927.

Gosatomnadzor of Russia (2001). Rules and Regulations NP-024-2000. Requirements for justification of the possibility to extend the design service life for nuclear facilities. Bulletin of Gosatomnadzor of Russia, 2, pp. 11-17.

Hannouz, S. (2014). Développement d'indicateurs pour la caractérisation mécanique et la durabilité des bois traités thermiquement. DSc Thesis in Engineering. Paris: Ecole nationale supérieure d'arts et métiers - ENSAM.

Interstate Council for Standardization, Metrology and Certification (2016). State Standard GOST 27.002-2015. Dependability in technics. Terms and definitions. Moscow: Standartinform, $23 \mathrm{p}$.

Khrulyov, V. M. (1981). Predicting durability of glue joints in wooden structures. Moscow: Stroyizdat, 128 p.

Köhler, J. (2006). Reliability of timber structures. DSc Thesis in Engineering. Zürich: EidgenössischeTechnische Hochschule - ETH Zürich.

Lamov, I. F. (1999). Improving durability and eco-friendliness of wooden residential buildings used in the climatic conditions of the North. PhD Thesis in Engineering. Arkhangelsk: Central Research Institute for Wood Machining (TsNIIMOD).

Perret, O. (2017). Strength and stability of cross-laminated-timber walls at short and long term. DSc Thesis in Engineering. Champssur-Marne: Université Paris-Est.

Ministry of Construction Industry, Housing and Utilities Sector of the Russian Federation (2017). Regulations SP 64.13330.2017. Timber structures. Revised edition of SNiP II-25-80 (Construction Rules and Regulations). Moscow: Standartinform, 97 p. 


\title{
ОЦЕНКА ОСТАТОЧНОГО РЕСУРСА ДЕРЕВЯННЫХ КОНСТРУКЦИЙ В УСЛОВИЯХ ПОВЫШЕННОЙ ВЛАЖНОСТИ
}

\author{
Александр Григорьевич Черных ${ }^{1}$, Дмитрий Игоревич Корольков ${ }^{2}$, Денис Валерьевич Нижегородцев ${ }^{3}$, Татьяна \\ Николаевна Казакевич ${ }^{4}$, Ширали Махаррамович Мамедов ${ }^{5}$
}

1,2,3,4,5Санкт-Петербургский государственный архитектурно-строительный университет 2-ая Красноармейская ул., 4, Санкт-Петербург, Россия

1E-mail: ag1825831@mail.ru

\begin{abstract}
Аннотация
Рассматривается вопрос применения уравнений регрессии для определения остаточного ресурса деревянных конструкций из различных пород древесины в условиях повышенной влажности. Цель исследования. Вывод формул расчета предельного срока эксплуатации деревянных конструкций для однофракторных уравнений регрессии в общем виде для последующего расчета остаточного ресурса (вариант №1) либо непосредственно для расчета остаточного ресурса (вариант №2). Методы. Используются однофакторные уравнения регрессии: линейное, логарифмическое, полиномиальное второй степени, степенное, экспоненциальное, показательное и гиперболическое. Результаты. Выведены уравнения в общем виде для расчета предельного срока службы древесины с последующим расчетом остаточного ресурса (вариант №1), а также уравнения для непосредственно расчета величины остаточного ресурса (вариант №2). Приведены достоинства и недостатки каждого из предложенных вариантов. Предложен алгоритм для обработки полученных результатов, если расчет ведется по нескольким уравнениям сразу. Приведен пример расчета величины остаточного ресурса по второму варианту. Обсуждение. С помощью предложенных зависимостей можно рассчитывать величину остаточного ресурса любых деревянных конструкций при любых условиях эксплуатации.
\end{abstract}

\section{Ключевые слова}

Остаточный ресурс, уравнения регрессии, деревянные конструкции, влажность. 